\title{
Return to work of breast cancer survivors: a systematic review of intervention studies
}

\author{
JL Hoving*, MLA Broekhuizen and MHW Frings-Dresen
}

Address: Coronel Institute of Occupational Health and Research Center for Insurance Medicine, Academic Medical Center, University of Amsterdam, Amsterdam, the Netherlands

Email: JL Hoving* - j.l.hoving@amc.uva.nl; MLA Broekhuizen - mbroekhu@gmail.com; MHW Frings-Dresen - m.frings@amc.uva.nl

* Corresponding author

Published: 21 April 2009

BMC Cancer 2009, 9:117 doi:10.1 186/147|-2407-9-117
Received: 25 August 2008

Accepted: 21 April 2009

This article is available from: http://www.biomedcentral.com/I47/-2407/9/II7

(c) 2009 Hoving et al; licensee BioMed Central Ltd.

This is an Open Access article distributed under the terms of the Creative Commons Attribution License (http://creativecommons.org/licenses/by/2.0), which permits unrestricted use, distribution, and reproduction in any medium, provided the original work is properly cited.

\begin{abstract}
Background: Breast cancer management has improved dramatically in the past three decades and as a result, a population of working age women is breast cancer survivor. Interventions for breast cancer survivors have shown improvements in quality of life and in physical and psychological states. In contrast, efforts aimed at stimulating re-employment and return-to-work interventions for breast cancer survivors have not kept pace. The objective of this review was to study the effects and characteristics of intervention studies on breast cancer survivors in which the outcome was return to work.
\end{abstract}

Methods: The Cochrane Controlled Trials Register (The Cochrane Library, Issue 4, 2006), Medline, Ovid, EMBASE and PsychInfo were systematically searched for studies conducted between 1970 to February 2007. Intervention studies for female breast cancer survivors that were focused on return to work were included.

Results: Our search strategy identified 5219 studies. Four studies out of 100 potentially relevant abstracts were selected and included 46-317 employed women who had had mastectomy, adjuvant therapy and rehabilitation, with the outcome return to work. The intervention programs focused on improvement of physical, psychological and social recovery. Although a substantial percentage (between $75 \%$ to $85 \%$ ) of patients included in these studies returned to work after rehabilitation, it is not clear whether this proportion would have been lower for patients without counseling or exercise, or any other interventions, as three out of four studies did not include a comparison group.

Conclusion: The most important finding of this review is the lack of methodologically sound intervention studies on breast cancer survivors with the outcome return to work. Using evidence from qualitative and observational studies on cancer and the good results of intervention studies on return to work programs and vocational rehabilitation, return to work interventions for breast cancer survivors should be further developed and evaluated. 


\section{Background}

Breast cancer detection and care management have undergone dramatic changes in the past three decades. Survival of breast cancer has become more frequent because women are increasingly diagnosed with early-stage disease and screening. Treatment is focused on curing the disease and preventing relapse due to metastatic disease. The overall five-year survival rate is now above $85 \%$ in The Netherlands [1] and USA [2].

These major advances in detecting and managing breast cancer have led to the treatment of women who are more likely to be of working age. For some women, breast cancer may impose an economic hardship because it causes them to leave their jobs [3]. Compared with women of similar age without a history of cancer, a slightly higher proportion of cancer survivors experience reduced work ability, temporarily as well as permanently, due to retirement or disability [4-6]. Being unable to return to work after cancer treatment, frequent or prolonged work absenteeism, or problems with work performance may have a substantial economic impact on the survivor and her family [7]. Job absenteeism is an important economic outcome because days missed from work are costly to both the employer and the employee. Moreover, it is stated that the longer people are absent from their jobs, the lower the likelihood is that they will ever return to work [8]. Return to work after breast cancer is important, not only from a societal point of view, but also for the rehabilitation of the cancer survivor $[9,10]$. Moreover, returning to or maintaining employment after cancer is important for survivors' quality of life, including physical and mental health [11].

In recent years, rehabilitation therapies have been developed for breast cancer survivors that focus on quality of life including physical and mental health. For example, interventions reported in observational studies that aim to improve quality of life for breast cancer survivors range from inpatient (spa) rehabilitation to telephone counselling [12-16]. The role of exercise for breast cancer patients has been examined for breast cancer-related side effects which may be especially important in patients who receive adjuvant treatment [17-19], though the number of studies is low and different types of exercise are used.

Most of these interventions show some improvement on quality of life or on other physical and psychological outcomes, such as cancer related fatigue, but do not pay attention to the aspect of work which is considered to be an important contributor to quality of life. For this reason we conducted a systematic review with the objective to study the effects and characteristics of intervention studies on breast cancer survivors in which the outcome was return to work.

\section{Methods \\ Identification of studies}

The literature search included a systematic review of the following electronic bibliographic databases: Medline Ovid, EMBASE, PsychInfo and the Cochrane Controlled Trials Register (The Cochrane Library, Issue 4, 2006). These databases were studied from 1970 to February 2007. Reference lists of relevant articles were scanned for any other relevant studies.

\section{Selection of studies}

All searches were conducted by one researcher (MLAB) and checked by another (JLH). All abstracts and titles were initially screened for relevance, i.e. whether it concerned an intervention study of female breast cancer survivors, and measured return to work.

The details of the search are listed in Appendix A.

The following inclusion criteria were applied for full text articles.

\section{(i) Types of Studies}

Randomised controlled studies (RCT), cohort studies and observational studies.

\section{(ii) Types of Participants}

Women who were diagnosed and had survived breast cancer with or without adjuvant therapy (i.e., chemotherapy, radiotherapy) during the intervention period.

\section{(iii)Types if Interventions}

All non-drug interventions.

\section{(iv) Types of Outcome Measures}

Studies that measured work-related outcomes such as: (a) return to work, (b) absenteeism, (c) work disability, (d) sick leave or (e) employment status.

\section{Data Extraction}

Data were extracted from the included papers by one reviewer (MLAB) and checked for accuracy by the second reviewer (JLH). Disagreement in data extraction between reviewers was solved by consensus. The extracted data included; first author, year and place of study, design, participant characteristics, description of intervention(s), length of follow up, outcomes and the effect of the interventions on return to work.

\section{Results}

Our search strategy revealed 5219 studies. Among these studies, 100 potentially relevant abstracts were identified. Following review of the full text articles, four full-length articles remained, each of which was eligible for inclusion [20-23]. The remaining 96 articles were excluded, mainly 
because these studies did not include work-related outcomes.

\section{Study characteristics}

Table 1 summarises the characteristics of the included studies [20-23]. In these four studies, 46-317 women who were working before the diagnosis of breast cancer were evaluated after a programme consisting of physical exercise and psychological counselling given individually or in group sessions by a specialized nurse or a team of specialists. Three out of four studies were published before 1990, and only one used a control group. Two studies described the same intervention, follow-up and outcomes, but in different hospital settings. The aim of all four studies was to improve physical and social recovery and adaptation to breast loss. Work status was reported as return to work percentages in all studies.

The only controlled study was reported by Maguire et al (1983)[20] in patients who had radical mastectomy and full axillary clearance. Half the weeks during a 24-month period were designated as 'counselling' weeks and the other half as 'control' weeks using a random number table. Women admitted for mastectomy in these weeks were assigned to the selected group for the duration of the study.

The counselling group comprised 75 women of which 42 worked before being diagnosed with breast cancer. These patients received individual care given by a specialist nurse who gave them help before and after surgery, in addition to the usual care of the surgical unit. During hospitalisation, counselling and advice was provided by showing patients how to carry out exercises designed to restore full mobility to the arm, and by encouraging the patient to look at the scar and discuss feelings regarding losing the breast. After discharge (length hospital stay was not specified), the intervention was continued at the woman's home. The specialized nurse checked the exercise program clarified how the woman felt about the scar and breast loss, and tried to ensure that the woman obtained a satisfactory prosthesis. The specialist nurse emphasized the value of the woman being open with her partner about the diagnosis and surgery. Furthermore, return to work and engagement in social activities were encouraged. The nurse followed each woman up every 2 months to monitor her progress unless it was already clear that the patient had adapted well. Details on the number of the visits were not specified.

The control group comprised 77 women, of whom 46 worked before the diagnosis of breast cancer. They received only the care normally given by the surgical unit. No specification of the usual care was given by Maguire et al [20]. The results of this study showed more favourable return-to-work rates in the counselling group $(\mathrm{n}=32$, $76 \%)$ compared with the control group $(\mathrm{n}=25,54 \%)$ within the 12 to 18 month follow-up period ( $\mathrm{p}<0.05)$.

Other outcomes, including response to scar, prosthesis and breast loss, showed that significantly more counselling than control patients displayed better results and had adapted well. With regard to housework and social adjustment, control subjects were less active than the counselled group.

The other three studies were non-controlled intervention studies [21-23]. Two studies referred to the same intervention, the "The Post Mastectomy Rehabilitation Group Program" (PMRG), in different hospital settings and different patients $[22,23]$. Both studies used a before-after design and reported that PMRG stimulated women to return to work and to resume normal activities [22,23].

Sachs et al (1980) included 107 patients who underwent only one type of mastectomy - a modified radical mastectomy with full axillary clearance (data Mt. Sinai Hospital) [22]. Pre-cancer work status was not mentioned in the study by Sachs [22]. Winick and Robbins (1977) included patients with different types of mastectomies, ranging from simple mastectomy, modified radical mastectomy, radical mastectomy and extended radical mastectomy [23]. In their study, 863 women were included of whom 317 women worked before the diagnosis of breast cancer.

The basic PMRG program included 'all' in-patient breast cancer patients that met for 90 minutes a day, five days a week. The multidisciplinary approach comprised a series of structural exercises, information and group therapy sessions which were conducted by a social worker, nurse or physical therapist. Additionally, one-on-one counselling by a volunteer from Reach to Recovery (not specified) was given. A key aspect of the PMRG was the manner in which the team of physicians, nurses, social workers and physical therapists operated. Each professional knew what the other team members did and needed to do. Moreover, the rest of the team understood how best to involve the physician in making the program work.

The women in these two studies were encouraged to attend the program on their second or third post-operative day, daily, until they were discharged $[22,23]$. Exercises were demonstrated by the physical therapist and lasted about half the time of most sessions. These exercises usually began on the patient's second or third postoperative day. Most patients were involved in at least two sessions led by the nurse, who provided a description of the various types of mastectomy surgeries and reviewed the importance of specific points about hand and arm care. Self-care was particularly stressed and taught. The social 
Table I: Summary characteristics of included studies

\begin{tabular}{|c|c|c|c|c|c|}
\hline Study & Participants & $\begin{array}{l}\text { Number of } \\
\text { subjects enrolled }\end{array}$ & $\begin{array}{l}\text { Description } \\
\text { intervention (s) }\end{array}$ & $\begin{array}{l}\text { Length of follow } \\
\text { up and outcomes }\end{array}$ & $\begin{array}{l}\text { Proportion returning } \\
\text { to work }\end{array}$ \\
\hline $\begin{array}{l}\text { Maguire, 1983, UK } \\
\text { Controlled trial }\end{array}$ & $\begin{array}{l}\text { Women undergoing modified } \\
\text { radical mastectomy and full } \\
\text { axillary clearance } \\
\text { Setting: surgical unit } \\
\text { Age: not mentioned }\end{array}$ & $\begin{array}{l}\mathrm{N}=152 \text { women, } \mathrm{N}=75 \text { in } \\
\text { counselling group and } \mathrm{N}=77 \\
\text { in care as usual group } \\
\text { Work status before cancer: } \\
\text { Counselling group } \mathrm{N}=42 \\
\text { Care as usual group } \mathrm{N}=46\end{array}$ & $\begin{array}{l}\text { Counselling group: } \\
\text { Counselling content: } \\
\text { - inpatient care: advice on } \\
\text { exercises, encouragement to } \\
\text { look at scar and discuss } \\
\text { feelings, discuss possible } \\
\text { external breast prosthesis } \\
\text { - at follow-up: encouragement } \\
\text { to return to work and } \\
\text { become socially active } \\
\text { Counselling frequency: } \\
\text { - inpatient care: pre- and } \\
\text { post- mastectomy } \\
\text { - at follow-up: after discharge, } \\
\text { every } 2 \text { months, home visits } \\
\text { until it was clear patient had } \\
\text { adapted well } \\
\text { Counselling was given by a } \\
\text { specialist nurse } \\
\text { Care as usual group: } \\
\text { Received usual care provided } \\
\text { by surgical unit }\end{array}$ & $\begin{array}{l}\text { Follow up: a few days after } \\
\text { surgery, } 3,12 \text { and } 18 \text { months. } \\
\text { Outcomes: assessed using a } \\
\text { semi-structured interview and } \\
\text { physical assessment: } \\
\text { - return to work } \\
\text { - house work } \\
\text { - social adjustment } \\
\text { - persisting problems arm: } \\
\text { pain, swelling, disability and } \\
\text { range of motion } \\
\text { - response to scar, prosthesis } \\
\text { and breast loss }\end{array}$ & $\begin{array}{l}\text { Return to work: } \\
\text { - Counselling group: } 76 \% \text { ( } 32 \\
\text { out of } 42 \text { patients) between } \\
\text { I } 2 \text { - } 18 \text { months } \\
\text { - Care as usual group: } 54 \% \\
\text { ( } 25 \text { out of } 46 \text { patients) } \\
\text { between } 12-18 \text { months } \\
\text { For return to work versus } \\
\text { not } \chi^{2}=4.59, p<0.05\end{array}$ \\
\hline $\begin{array}{l}\text { Fismen, } 2000 \text {, Norway } \\
\text { Non-Controlled study }\end{array}$ & $\begin{array}{l}\text { Women who had received } \\
\text { surgical treatment, } \\
\text { chemotherapy and radiation } \\
\text { therapy for breast cancer } \\
\text { (stage I and 2), in } \\
\text { combination with } \\
\text { rehabilitation } \\
\text { Setting: surgical unit } \\
\text { Age: } 31-66 \\
\text { (mean } 49 \text { years) }\end{array}$ & $\begin{array}{l}N=50 \text { women } \\
\text { Work status before cancer: } N \\
=46\end{array}$ & $\begin{array}{l}\text { Content: } \\
\text { Training of physical capacity; } \\
\text { cognitive group discussions in } \\
\text { small groups } \\
(2-10 \text { persons }) \\
\text { Examinations of psychological } \\
\text { and physical status were } \\
\text { performed before } \\
\text { rehabilitation, after } \\
\text { rehabilitation and after follow- } \\
\text { up } \\
\text { Frequency: } 3 \text { weeks } \\
\text { rehabilitation program, } 3 \\
\text { months at home and I week } \\
\text { follow up at rehabilitation } \\
\text { centre. }\end{array}$ & $\begin{array}{l}\text { Follow-up: } \\
\text { - after } 3 \text { weeks rehabilitation } \\
\text { - after } 3 \text { months at home } \\
\text { - after I week follow-up in } \\
\text { rehabilitation centre } \\
\text { Outcomes: assessed by } \\
\text { questionnaires: } \\
\text { - return to work } \\
\text { - mental state } \\
\text { (depression, anxiety, mood } \\
\text { states) } \\
\text { - quality of life and pain. } \\
\text { In addition, assessment of } \\
\text { lymph edema and VO2 max }\end{array}$ & $\begin{array}{l}\text { Return to work: } \\
78 \% \text { ( } 36 \text { out of } 46 \text { patients) } \\
\text { during the } 3 \text { month follow-up }\end{array}$ \\
\hline
\end{tabular}


Table I: Summary characteristics of included studies (Continued)

\begin{tabular}{|c|c|c|c|c|c|}
\hline $\begin{array}{l}\text { Sachs, 1980, } \\
\text { USA } \\
\text { Non-Controlled study }\end{array}$ & $\begin{array}{l}\text { Women who underwent } \\
\text { modified radical mastectomy } \\
\text { and full axillary clearance (Mt. } \\
\text { Sinai data) and rehabilitation } \\
\text { Setting: surgical unit } \\
\text { Age: not mentioned }\end{array}$ & $\begin{array}{l}\mathrm{N}=107 \text { women } \\
\text { Work status before cancer: } \\
\text { not mentioned }\end{array}$ & $\begin{array}{l}\text { Content: } \\
\text { - counselling: emotional } \\
\text { support, encouragement to } \\
\text { look at scar, discuss feelings, } \\
\text { discuss possible external } \\
\text { breast prosthesis, } \\
\text { encouragement to return to } \\
\text { work and become socially } \\
\text { active } \\
\text { - exercises } \\
\text { Frequency: } \\
90 \text { minutes a day, } 5 \text { days a } \\
\text { week until discharge from } \\
\text { hospital } \\
\text { - counselling: on alternating } \\
\text { days } \\
\text { - exercises: daily } \\
\text { Professionals involved: } \\
\text { A team consisting of a physical } \\
\text { therapist, a nurse, a social } \\
\text { worker, and a Reach-To- } \\
\text { Recovery volunteer for } 3 \text { days } \\
\text { each week } \\
\text { Counselling: } \\
\text { - mastectomy rehabilitation } \\
\text { nurse: visits with patient } \\
\text { before and after operation, } \\
\text { informs patient and family of } \\
\text { programme, lends moral } \\
\text { support } \\
\text { - social worker: leads groups } \\
\text { sessions in the programme } \\
\text { Exercises: } \\
\text { - demonstrated by physical } \\
\text { therapist and performed daily } \\
\text { The physician was a member } \\
\text { of the team }\end{array}$ & $\begin{array}{l}\text { Follow up: } 90 \text { days after } \\
\text { discharge a questionnaire was } \\
\text { sent to the participating } \\
\text { patients } \\
\text { Outcomes: assessed using } \\
\text { questionnaires: } \\
\text { - return to work } \\
\text { - resumption of normal } \\
\text { activities } \\
\text { - physical recovery and } \\
\text { rehabilitation } \\
\text { - emotional stress }\end{array}$ & $\begin{array}{l}\text { Return to work: } \\
85 \% \text { of patients. Average } \\
\text { duration out of work: } 5.9 \\
\text { weeks }\end{array}$ \\
\hline
\end{tabular}




\begin{tabular}{|c|c|c|c|}
\hline $\begin{array}{l}\text { Winick, 1977, USA } \\
\text { Non-Controlled study }\end{array}$ & $\begin{array}{l}\text { Women who underwent } \\
\text { *Simple or total mastectomy: } \\
\text { **Modified radical } \\
\text { mastectomy: + axillary lymph } \\
\text { nodes and part pectoral } \\
\text { muscle } \\
* * * \text { Standard or radical } \\
\text { mastectomy: + lymph nodes } \\
\text { and underlying pectoral } \\
\text { muscles ****Extended radical } \\
\text { mastectomy; + all } \\
\text { axillary lymph nodes, } \\
\text { underlying pectoral muscles, } \\
\text { and medial } \\
\text { segment chest wall } \\
\text { All women received } \\
\text { rehabilitation } \\
\text { Setting: surgical unit } \\
\text { Age: } 20-91 \\
\text { (mean } 56 \text { years) }\end{array}$ & $\begin{array}{l}\mathrm{N}=863 \text { women } \\
\text { Work status before cancer: } \mathrm{N} \\
=317 \text { employed full time }\end{array}$ & $\begin{array}{l}\text { Same Post Mastectomy } \\
\text { Rehabilitation Programme as } \\
\text { study by Sachs et al. }\end{array}$ \\
\hline
\end{tabular}

Follow up: 3 months after

discharge

Outcomes: assessed using a

Return to work:

questionnaire sent to patients:

- return to work

- resumption of norma

activities

- physical recovery and

rehabilitation

- emotional stress and

personal relationship

adjustment difficulties

$*$ : $(\mathrm{n}=2)$,

resume: 3

$75 \%$ of patients ( 237 out of

317 patients) full time return

to work within 3 months:

$100 \%$, average weeks to

**: $(n=50), 78 \%$, average

weeks to resume: 7.1

***: $(n=24 I), 75 \%$, average weeks to resume: 8.6

***: $(n=24), 63 \%$, average

weeks to resume: 9.5 (mean 56 years) 
worker led discussions on alternating days. It offered women in the group an opportunity to deal with their grief and fear in a setting with others experiencing similar emotions. In cases in which the woman's fear appeared more pervasive, individual counselling was given. During the counselling period, patients were encouraged to return to work and to become socially active again after discharge.

Winick and Robbins reported that the type of surgical procedure influenced recovery time, adaptation and return to work [23]. Patients who had less extensive surgery returned to work in less time compared to patients who had more extensive surgery. Two women had only a breast removed, a simple mastectomy and both returned to work in an average of 3 weeks. On the other hand, of the women who had extended radical mastectomy, which comprised of the removal of the breast with all axillary lymph nodes, the underlying pectoralis muscles and the medial segment of the chest overlying the internal mammary nodes and the internal mammary nodes, $63 \%(n=$ 24) returned to work in a average of 9,5 weeks.

The more recent, non-controlled study by Fismen et al (2000) reported an intervention study on 50 women who had undergone surgical treatment, chemotherapy and radiation therapy [21]. Sixty-four of these women worked before the diagnosis of breast cancer. The study describes a three-week rehabilitation program of physical and psychological interventions. It was followed by a threemonth period at home and a one-week follow-up at the rehabilitation center. Training of physical capacity and cognitive group discussions were given in small groups ( $\mathrm{n}$ $=2-10)$. After rehabilitation, 36 out of $46(78 \%)$ women returned to work. In addition, there was an improvement in psychological parameters and an increase in the maximum oxygen uptake (from $67 \%$ to $77 \%$ ) during the threemonth follow-up.

\section{Discussion}

The objective of this review was to study the effects and characteristics of intervention studies on breast cancer survivors in which the outcome was return to work. After an extensive literature review we identified only four intervention studies that measured return to work, three of which published more than 25 years ago. Although return-to-work rates around $75 \%-85 \%$ after up to 18 months follow up seem favourable, the lack of recently published high quality trials limits the strength of the evidence observed in these four studies.

It is not clear whether return to work would have been lower without rehabilitation consisting of counseling or exercise, or no intervention, as three out of four studies did not include a comparison group. A recent surveillance study by Bouknight et al (2006) in the US, found $82 \%$ of breast cancer survivors returned to work after 12 months [24]. These results are in contrast with a return to work rate of $56 \%$ reported in a Spanish breast cancer questionnaire study [25]. There is a wide range in disability outcomes among breast cancer survivors, even when they have had the same disease with equal severity [26]. Sick leave is on average about a year, but nevertheless varies from a couple of days to a couple of years. Though in the similar range, any comparisons between return to work rates observed in our review and recent survey studies are difficult to make as breast cancer survivor populations, medical procedures, rehabilitation strategies, and social security and health insurance provisions are not likely to be comparable.

On the other hand, return-to-work rates from more than two decades ago would likely be lower compared to today, as cancer related morbidity is lower and survival has significantly improved due to medical advances. Despite better medical treatment and physical and psychosocial rehabilitation, a five year follow up update of the Fismen et al study (2000) on the same study population reported that $23 \%$ of patients had died of cancer, depression and anxiety were similar to the situation directly post-rehabilitation, and almost half (44\%) of the remaining patients had lost their job compared to $22 \%$ three months after surgery [27].

Of interest, the included studies $[20,23]$ indicated that longer time needed to return to work was related to more extensive surgical procedures. In any case, time needed to return to work may be a more important outcome if absolute return-to-work rates continue to improve as some of these high return to work rates suggest.

Given the limitations of the three older studies and the somewhat sobering results of the recent Fisman study, we believe that return to work rates outcomes can be further improved. In addition to design issues and the quality of medical care, it is important to understand that return to work in this review was not the primary aim for any of the four studies included, but rather improvement of "physical and social recovery" in the context of a more 'traditional' rehabilitation context. In all four studies this included instructions or advice on specific exercises, for example to mobilise the shoulder or more general training of physical capacity, both of varying frequency and given in groups, individually or solely as a home assignment. In conjunction, counselling was part of a pre- and post operative care program and provided by a specialized nurse or social worker who provided support, encouragement, advice and openness to discuss feelings. Tailoring the exercise and counselling content specifically towards vocational outcomes (like return to work) was not appar- 
ent in any of the descriptions of these four studies and was, as explained earlier, not a specific long term goal.

Short et al (2005) showed that when work issues are addressed as a part of treatment, return to work is more successful after cancer [28]. Although the literature on breast cancer does not provide us with much information regarding interventions which are specifically targeted at vocational outcomes such as return to work, there is research from studies on cancer and other diseases in the occupational health literature which could be applied to improve return to work outcomes for breast cancer survivors. The issue of return to work should be addressed in intervention studies [29]. This includes more attention, information, support, and advice on work issues, not only by health care professionals but also by employers.

Rehabilitation needs of cancer patients focus around fatigue, reinforcing physical working capacity and psychosocial functioning [30]. In addition to prolonged physical or mental fatigue, qualitative research has also identified personal problems such as cognitive limitations, difficulty mobilising support, difficulty managing stress and anxiety, difficulty coping with a new self image, and changed attitude to work [24,31-34]. As mentioned above, both exercise and counselling seem good alternatives to deal with these problems that patients experience but could be further improved upon by including work resumption as a specific long term goal.

Work factors that could be positively targeted for interventions deal with, for example, good communication with co-workers and employers, early contact with the workplace, or work accommodations such as flexibility regarding work hours [34-36]. In addition, there is evidence that special arrangements made by the employer such as gradual return to work facilitates return to work [37]. Vocational rehabilitation or return-to-work programs target the barriers and facilitators for the return to work issues listed above and have been successfully applied in the area of rheumatoid arthritis [38] and other diseases [37,39].

Several rehabilitation strategies have proven valuable for patients with cancer or other diseases. For example, graded activity, a theory that promotes a step by step increase in activity, is beneficial for cancer patients to deal with fatigue and functioning [15]. In addition, workplace interventions such as work modifications and case management involving all stakeholders has been successfully applied for the return to work of workers with low back pain $[40,41]$. Also, cancer survivors may benefit from advice to structure the return to work process and use goal-setting during rehabilitation $[42,43]$. Verbeek and Spelten (2007) introduced a 10-step plan for return to work that was tested among cancer survivors at a radio- therapy department. The plan consists of a fixed scheme with the end-point return to work starting early in the rehabilitation process and in collaboration with the employer [29].

In this review the number of rehabilitation visits in the included studies is quite low. The duration of traditional rehabilitation is often limited to a maximum of about three months after surgery and this period may not be long enough to support patients who are in the process of returning to work. Therefore, if duration of functional capacity is to be really improved $[19,44]$ it is suggested that rehabilitation programs are also of adequate duration, frequency and intensity. Additionally, changing psychosocial outcomes, behaviour in particular, may require more intensive intervention strategies during the complex return-to-work process over a longer period of time [43].

\section{Conclusion}

In conclusion, the most important finding of this review is the lack of intervention studies that are focused on return to work. Using evidence from qualitative and observational studies on cancer and other diseases, and the good results of studies on return to work programs and vocational rehabilitation, return to work interventions for breast cancer survivors should be further developed and evaluated. Ultimately this may lead to a better quality of life and functioning, improve social economic outcomes, and a quicker return to work for breast cancer survivors.

\section{Competing interests}

The authors declare that they have no competing interests. No financial support was sought in the production of this article.

\section{Authors' contributions}

All authors have made substantial contributions to acquisition and analysis of data. JLH and MLAB have been involved in drafting the manuscript. MHW has been involved in the data extraction and in revising the manuscript critically for important intellectual content. Each author has participated sufficiently in the work and takes responsibility for appropriate portions of the content. All authors have read and have given final approval of the version to be published.

\section{Appendix A}

A) Identification of breast cancer studies

1) (("breast neoplasms" [TIAB] NOT Medline [SB]) OR "breast neoplasms" [MeSH Terms] OR breast cancer [Text Word]) AND "humans" [MeSH Terms]

B) Identification of intervention studies 
2) text words

effectiveness [tw] OR program [tw] OR intervention [tw] OR reduction [tw] OR effect\$ [ti] OR evaluation [tw] OR decrease\$ [tw] OR "prevention and control" [sh] OR measures [tw] OR improve\$ [tiab] OR educat\$ [tw] OR training [tw] OR rehabilitation [tw]

\section{3) type design - use of PT and MESH}

randomized controlled trial [pt] OR controlled clinical trial [pt] OR randomized controlled trials [mh] OR random allocation [mh] OR double-blind method [mh] OR single-blind method [mh] OR clinical trial [pt] OR clinical trials [mh] OR "clinical trial" [tw] OR comparative study [pt] OR evaluation studies [MeSH Terms] OR evaluation studies [mh] OR follow-up studies [mh] OR prospective studies [mh] OR cross-over studies [mh] OR treatment outcome [mh] OR "time series" [tw]

4) sensitive search

effect\$ [tw] OR control\$ [tw] OR evaluat\$ [tw] OR compare $\$[\mathrm{tw}]$ program $\$[\mathrm{tw}]$ outcome\$ $[\mathrm{tw}]$

C) Identification of studies with relevant outcomes/or studies that include a work related term

5) work related outcomes:

"return to work" [tw] OR absenteeism OR "sickness absence" [tw] OR sick leave OR retirement OR "disability pension" OR "work disability" [tw] OR unemployment OR employment OR "work status" [tw] OR "work ability" [tw] OR "employment status" [tw]

6) OR "quality of life" [MeSH Terms] OR "quality of life" [tw]

7) OR fatigue [tw]

8) work related terms:

OR occupation\$ OR "occupational health services" OR "occupational health" OR unemployed OR employed OR job OR vocational OR (occupational AND therap\$) OR (occupational AND intervention\$) OR "supported employment" OR "vocational rehabilitation" [tw] OR "work capacity evaluation" [tw] OR "vocational guidance" [tw] OR "work load"

\section{References}

I. Coebergh JWW, Janssen-Heijen MLG, Louwman WJ, Eds: Cancer incidence and survival in the South of the Netherlands 19551999. Eindhoven, Comprehensive Cancer Centre South (IKZ) $200 \mathrm{I}$.
2. Brenner H, Gondos A, Arndt V: Recent major progress in longterm cancer patient survival disclosed by modelled period analysis. J Clin Onco 2007, 25:3274-3280.

3. Bradley CJ, Bednarek HL, Neumark D: Breast cancer and women's labor supply. Health Serv Res 2002, 37:1309-1328.

4. Bradley CJ, Bednarek HL, Neumark D: Breast cancer survival, work, and earnings. J Health Econ 2002, 2 I:757-779.

5. Bradley CJ, Neumark D, Bednarek HL: Short term effects of breast cancer on labor market attachment: Results from a longitudinal study. J Health Econ 2005, 24:137-60.

6. Taskila T, Martikainen R, Hietanen P, Lindbohm M: Comparative study of work ability between cancer survivors and their referents. Europ J of Cancer 2007, 43:914-920.

7. Chirikos TN, Russell-Jacobs A, Cantor AB: Indirect economic effects of long-term breast cancer survival. Cancer Pract 2002, 10:248-255.

8. Peteet JR: Cancer and the meaning of work. Gen Hosp Psychiat 2000, 22:200-205.

9. Clark JC, Landis LL: Reintegration and maintenance of employees with breast cancer in the workplace. AAOHN 1989, 37:186-193.

10. Mellette SJ: The cancer patient at work. CA Cancer J Clin 1985, 35:360-373.

II. Anderson N, Armstead CA: Toward understanding the association of socioeconomic status and health: a new challenge for the biopsychosocial approach. Psychosom Med 1995, 57:2 13-225.

12. Wouden J Van der, Greaves-Otte J, Greaves J, Kruyt PM, van Leeuwen $O$, Does $E$ van der: Occupational reintegration of longterm cancer survivors. J Occup Med 1992, 34: 1084- 1089.

13. Strauss-Blasche G, Gnad E, Ekmekcioglu C, Hladschik B, Marktl W: Combined inpatient rehabilitation and Spa therapy for breast cancer patients. Effects on quality of life and CA 15-3. Cancer Nursing 2005, 28(5):390-398.

14. Sandgren AK, McCaul KD: Long-term telephone therapy outcomes for breast cancer patients. Psycho-Oncology 2007, 16:38-47.

15. Korstjens I, Mesters I, Peet E van der, Gijsen B, Borne B van den: Quality of life of cancer survivors after physical and psychosocial rehabilitation. Eur / Cancer Prev 2006, I 5(6):54|-547.

16. Mock V, Pickett M, Ropka ME, Muscari E, Stewart KJ, Rhodes VA, McDaniel R, Grimm PM, Krum S, McCorkle R: Fatigue and quality of life outcomes of exercise during cancer treatment. Cancer Practice 200I, 9(3): I 19-127.

17. Jacobsen PB, Jim HS: Psychosocial interventions for anxiety and depression in adult cancer patients: achievements and challenges. CA Cancer J Clin 2008, 58(4):214-230.

18. Cramp F, Daniel J: Exercise for the management of cancerrelated fatigue in adults (Review). Cochrane Database Syst Rev 2008.

19. De Backer IC, Vreugdenhil G, Nijziel MR, Kester AD, van Breda E, Schep G: Long-term follow-up after cancer rehabilitation using high-intensity resistance training: persistent improvement of physical performance and quality of life. $\mathrm{Br} J$ Cancer 2008, 99:30-6.

20. Maguire P, Brooke M, Tait C, Sellwood TR: The effect of counselling on physical and social recovery after mastectomy. Clin Oncol 1983, 9:319-324.

21. Fismen K, Osland IJ, Fismen E, Borge L, Martinsen EW, Hjort P, Iversen $\mathrm{O}$, Stanghelle JK: Rehabilitation of women with breast cancer. Tidsskr Nor Laegeforen 2000, I 20(23):2749-2754.

22. Sachs SH, Davis JM, Reynolds SA, Spagnola M, Hall P, Bloch A: Postmastectomy rehabilitation in a community hospital. J Family Pract 1980, I I (3):395-40I.

23. Winick L, Robbins GF: Physical and psychologic readjustment after mastectomy. Cancer 1977, 39:478-486.

24. Bouknight RR, Bradley CJ, Luo Z: Correlates of return to work for breast cancer survivors. J Clin Oncol 2006, 24(3):345-53.

25. Villaverde RM, Battle JF, Yllan AV, Yllan AV, Gordo AYY, Sanchez AR, Valiente BSJ, Baron MG: Employment in a cohort of breast cancer patients. Occup Med 2008, 58:509-5 I I.

26. Spelten ER, Verbeek JH, Uitterhoeve AL, Ansink AC, van der LJ, de Reijke TM, Kammeijer M, de Haes JC, Sprangers MA: Cancer, fatigue and the return of patients to work-a prospective cohort study. European Journal of Cancer 2003, 39:1562-1567. 
27. Fismen K, Stanghelle JK: Rehabilitation of women with breast cancer; five-year follow-up. Tidsskr Nor Laegeforen 2007, 1 27:1207-9.

28. Short PF, Vasey J], Tunceli K: Employment pathways in a large cohort of adult cancer survivors. Cancer 2005, I 03:I292-30I.

29. Verbeek J, Spelten E: Work. In Handbook of cancer survivorship Edited by: Michael Feuerstein. Springer; 2007.

30. van Harten WH, van NO, Warmerdam R, Hendricks $H$, Seidel E: Assessment of rehabilitation needs in cancer patients. Int J Rehabil Res 1998, 2 I:247-57.

31. Berry DL, Catanzaro M: Persons with cancer and their return to the workplace. Cancer Nursing 1992, I 5:40-46.

32. Maunsell E, Brisson C, Dubois L, Lauzier S, Fraser A: Work problems after breast cancer: an exploratory qualitative study. Psychooncology 1999, 8:467-73.

33. Kennedy F, Haslam C, Munir F, Pryce J: Returning to work following cancer: a qualitative exploratory study into the experience of returning to work following cancer. Eur J Cancer Care 2007, I 6:17-25.

34. Pryce J, Munir F, Haslam C: Cancer survivorship and work: symptoms, supervisor response, co-worker disclosure and work adjustment. J Occup Rehabil 2007, I 7:83-92.

35. Nachreiner NM, Dagher RK, McGovern PM, Baker BA, Alexander $\mathrm{BH}$, Gerberich SG: Successful return to work for cancer survivors. AAOHN J 2007, 55:290-295.

36. Amir Z, Neary D, Luker K: Cancer survivors' views of work 3 years post diagnosis: a UK perspective. Eur J Oncol Nurs 2008, 1 2:190-197.

37. Franche R, Cullen K, Clarke J, Irvin E, Sinclair S, Frank J: Workplace-based return-to-work interventions: a systematic review of the quantitative literature. J Occup Rehab 2005, I 5:607-63|.

38. Allaire $\mathrm{SH}$, Li W, LaValley MP: Reduction of job loss in persons with rheumatic diseases receiving vocational rehabilitation. Arthritis \& Rheumatism 2003, 48:3212-3218

39. Braathen TN, Veiersted KB, Heggenes J: Improved work ability and return to work following vocational multidisciplinary rehabilitation of subjects on long-term sick leave. J Rehabil Med 2007, 39:493-9.

40. Anema JR, Steenstra IA, Bongers PM, de Vet HC, Knol DL, Loisel P, van Mechelen W: Multidisciplinary rehabilitation for subacute low back pain: graded activity or workplace intervention or both? A randomized controlled trial. Spine 2007, 32:291-8.

4I. Loisel P, Gosselin L, Durand P, Lemaire J, Poitras S, Abenhaim I: Implementation of a participatory ergonomics program in the rehabilitation of workers suffering from subacute back pain. Appl Ergon 200I, 32:53-60.

42. Siegert RJ, Taylor WJ: Theoretical aspects of goal-setting and motivation in rehabilitation. Disabil Rehabil 2004, 26: I-8.

43. Nieuwenhuijsen K, Bos-Ransdorp B, Uitterhoeve LL, Sprangers MA, Verbeek JH: Enhanced provider communication and patient education regarding return to work in cancer survivors following curative treatment: a pilot study. J Occup Rehabil 2006, 1 6:647-657.

44. Pinto BM, Maruyama NC: Exercise in the rehabilitation of breast cancer survivors. Psychooncology 1999, 8:191-206.

\section{Pre-publication history}

The pre-publication history for this paper can be accessed here:

http://www.biomedcentral.com/1471-2407/9/117/pre pub Publish with Biomed Central and every
scientist can read your work free of charge

"BioMed Central will be the most significant development for disseminating the results of biomedical research in our lifetime. "

Sir Paul Nurse, Cancer Research UK

Your research papers will be:

- available free of charge to the entire biomedical community

- peer reviewed and published immediately upon acceptance

- cited in PubMed and archived on PubMed Central

- yours - you keep the copyright

Submit your manuscript here:

http://www.biomedcentral.com/info/publishing_adv.asp
BiolMedcentral 